\title{
Keragaman Fusarium pada Rizosfer Tanaman Kacang Panjang dan Peranannya bagi Pertumbuhan Tanaman
}

\author{
Rhizosphere Fusarium Diversity and Its Role on \\ The Plant Growth of Yard Long Bean
}

\author{
Rahmi Sutrisni dan Widodo* \\ Institut Pertanian Bogor, Bogor 16680
}

\begin{abstract}
ABSTRAK
Salah satu penyakit penting pada tanaman kacang panjang ialah layu Fusarium yang disebabkan oleh Fusarium oxysporum f.sp. tracheiphilum. Selain berperan sebagai patogen terhadap tanaman, beberapa spesies Fusarium juga diketahui bersifat non patogen dan mampu mengendalikan penyakit layu Fusarium seperti yang terjadi secara alami pada kasus tanah supresif. Penelitian ini bertujuan menentukan keragaman cendawan Fusarium pada rizosfer tanaman kacang panjang dan peranannya bagi pertumbuhan tanaman. Dari total 56 isolat, 4 spesies Fusarium teridentifikasi sebagai, F. oxysporum (39.3\%), F. semitectum (28.6\%), F. longipes (12.5\%), F. solani (5.3\%), dan satu Fusarium sp. tidak teridentifikasi (14.3\%) ditemukan selama penelitian. Indeks keragaman Fusarium tertinggi diperoleh dari lahan pertanaman kacang panjang yang sebelumnya ditanami dengan jagung. Secara umum dari 56 isolat yang diujikan pengaruhnya terhadap tanaman dikelompokkan menjadi tiga, yaitu bersifat merugikan yang menyebabkan gejala kelayuan atau menekan pertumbuhan tanpa gejala kelayuan (50.0\%), netral yang pertumbuhannya tidak berbeda jauh dengan kontrol (41.1\%), dan memicu pertumbuhan (8.9\%). Semua isolat yang dapat menyebabkan gejala kelayuan teridentifikasi sebagai $F$. oxysporum, sedangkan isolat dengan kemampuan memicu pertumbuhan tanaman adalah $F$. oxysporum dan $F$. solani yang bersifat non patogen dan mampu mengendalikan $F$. oxysporum patogen ketika dilakukan koinokulasi.
\end{abstract}

Kata kunci: Fusarium, kacang panjang, keragaman, rizosfer

\section{ABSTRACT}

Fusarium wilt caused by Fusarium oxysporum f.sp. tracheiphilum is one of the important diseases on yard long bean. Besides of its capability of causing diseases in plants, some species of Fusarium are non pathogenic and able to control Fusarium wilt as naturally occured in disease suppressive soils. The objective of this study was to observe the rhizosphere Fusarium diversity and its role on the plant growth of yard long bean. Out of 56 isolates collected during the study, four species were identified, including F. oxysporum (39.3\%), F. semitectum (28.6\%), F. longipes (12.5\%), F. solani (5.3\%), and one unidentified Fusarium sp. (14.3\%). The highest diversity index was obtained from the field planted with corn as previous crop. In general, 56 isolates tested could be differentiated into 3 groups based on their effects on plan growth, i.e.: deleterious that caused wilting or growth suppressive without wilting $(50.0 \%)$, neutral that no significantly difference growth as untreated $(41.1 \%)$, and growth promoting (8.9\%). All three isolated Fusarium causing plant wilting identified as F. oxysporum, while isolates with growth promoting effect were identified as $F$. oxysporum (4 isolates) and $F$. solani (1 isolate). These five selected growth promoting Fusarium also suppressed the wilt disease and increased the plant growth when co inoculated with wilt pathogen of yard long bean, F. oxysporum f.sp. tracheiphillum.

Key words: diversity, Fusarium, long yard bean, rhizosphere

\footnotetext{
*Alamat penulis korespondensi: Departemen Proteksi Tanaman, Fakultas Pertanian, Institut Pertanian Bogor, Kampus Darmaga, Jalan Kamper, Bogor 16680

Tel: 0251- 8629364, Faks: 0251- 8629362, Surel: widodo@ipb.ac.id
} 


\section{PENDAHULUAN}

Kacang panjang (Vigna sinensis) merupakan tanaman yang umum dijumpai di Indonesia, khususnya di Pulau Jawa. Salah satu masalah yang dihadapi dalam budi daya kacang panjang ialah penyakit layu yang disebabkan oleh Fusarium oxysporum f. sp. tracheiphillum. Adanya penyakit pada tanaman menunjukkan bahwa tidak terjadi keseimbangan biologi di alam.

Di dalam tanah terdapat berbagai tipe interaksi antarmikroorganisme yang berperan dalam proses untuk mencapai keseimbangan biologi. Akibat interaksi tersebut ialah perangsangan atau penghambatan pertumbuhan organisme, perangsangan atau penghambatan pembentukan spora rehat, dormansi, dan penyebab lisis terhadap organisme lainnya.

Fusarium merupakan cendawan yang mampu hidup dalam berbagai ekosistem, termasuk tanah dan perakaran tanaman, serta tersebar luas di berbagai belahan dunia. Cendawan ini juga memiliki pengaruh penting terhadap kehidupan manusia, karena berperan sebagai patogen pada tanaman maupun manusia, dan menghasilkan toksin (Summerell et al. 2011). Selain peranan yang merugikan di salah satu sisi, Fusarium juga mempunyai peranan sebagai parasit pada tanaman, tetapi tidak merugikan tanaman tersebut dan bahkan dapat menekan penyakit dan meningkatkan pertumbuhan tanaman. Fusarium ini dapat hidup di dalam jaringan korteks tanpa menyebabkan gejala penyakit (Appel dan Gordon 1994) dan dapat bersifat antagonis terhadap Fusarium patogen yang berada di dalam tanah (Edel et al. 1997; Forsyth et al. 2006; ).

Fusarium diketahui sebagai salah satu cendawan yang mampu mengolonisasi perakaran tanaman dengan baik. Beberapa spesies Fusarium yang telah diidentifikasi mengolonisasi tanaman lentil (Lens culinaris) dan wijen (Sesamum indicum) antara lain, $F$. solani, F. tricinctum, F. nygamai, F. verticillioides, $F$. poae, $F$. acutatum, dan $F$. longipes (AbdelHafez et al. 2012). Sementara itu peneliti lain menyatakan beberapa spesies Fusarium, seperti $F$. oxysporum, $F$. proliferatum, $F$. moniliforme, $F$. solani, $F$. equiseti, dan F. graminearum merupakan rhizozphere competent pada tanaman jagung (Ocamb dan Kommedahl 1994). Meera et al. (1994) melaporkan Fusarium, Penicillium, Rhizopus, dan Trichoderma yang dikoleksi dari rizosfer Capsicum annuum, Solanum melongena, Triticum aestivum, Zea mays, dan Zoysia tenuifolia meningkatkan pertumbuhan berbagai tanaman pertanian. Selain mengoloni perakaran tanaman, dua spesies Fusarium, yaitu $F$. solani dan $F$. oxysporum banyak disolasi dari tanah hutan di Malaysia (Latifah et al. 2009). Di antara berbagai spesies Fusarium yang mengoloni perakaran tanaman, diantaranya ada yang bersifat non patogenik dan mampu menekan Fusarium patogen (Scisel et al. 2008, Kaur et al. 2010). Fusarium dari rizosfer kacang panjang diharapkan mampu memberikan peranan terhadap pertumbuhan tanaman.

\section{BAHAN DAN METODE}

\section{Isolasi, Koleksi, dan Identifikasi Fusarium spp.}

Cendawan diisolasi dari rizosfer tanaman kacang panjang dari Desa Cihideung Girang, Kecamatan Ciampea; Desa Sukawening, Kecamatan Dramaga, Kabupaten Bogor; dan Desa Situgede, Kecamatan Bogor Barat Kotamadya Bogor.

Sampel pada masing-masing lahan diambil dari tiga tempat secara diagonal. Tanah diambil dari daerah sekitar perakaran tanaman. Setiap tempat dilakukan lima kali pengambilan tanah sampel, kemudian diaduk secara merata sebagai contoh komposit. Sebanyak $10 \mathrm{~g}$ tanah bersama dengan akar yang terambil dari contoh komposit dimasukkan ke dalam botol erlenmeyer $250 \mathrm{~mL}$ yang berisi $90 \mathrm{~mL}$ air steril. Botol erlenmeyer ditutup kemudian dikocok dengan menggunakan pengocok putar (rotary shaker) selama 30 menit dengan kecepatan $200 \mathrm{rpm}$. Sebanyak $0.1 \mathrm{~mL}$ suspensi tersebut disebar rata pada cawan yang berisi 
medium PCNB Agar (Nash dan Snyder 1962) dan diinkubasi selama 5-7 hari pada suhu ruang.

Semua koloni cendawan Fusarium yang muncul pada medium PCNB Agar diremajakan pada medium potato dextrose agar (PDA) dan diinkubasi selama 5-7 hari. Semua isolat Fusarium dibuat biakan spora tunggal menggunakan medium agar-agar air. Biakan murni dari spora tunggal disimpan pada medium PDA sebagai koleksi biakan dan diidentifikasi menggunakan kunci Toussoun dan Nelson (1975), Summerell et al. (2003), serta Leslie dan Summerell (2006).

Jumlah dan jenis biakan murni spora tunggal Fusarium yang diperoleh dari masingmasing lahan dihitung untuk menentukan keragamannya. Indeks keragaman Fusarium pada masing-masing lahan dihitung menggunakan rumus indeks keragaman ShannonWeaner (Krebs 1972).

\section{Uji Peranan Isolat Fusarium pada Kacang Panjang}

Isolat Fusarium diperbanyak pada medium PDA dan diinkubasi selama 7 hari. Cawan yang berisi koloni Fusarium tersebut ditambah $10 \mathrm{~mL}$ air steril dan diratakan menggunakan spatula sehingga didapatkan suspensi yang berisi massa konidium. Suspensi tersebut dihitung jumlah konidiumnya menggunakan haemasitometer. Kepadatan konidium yang digunakan untuk inokulasi ialah $10^{6} \mathrm{~g}^{-1}$ tanah.

Benih kacang panjang disemai dalam pot berukuran $15 \mathrm{~cm}$ x $20 \mathrm{~cm}$ yang berisi tanah dan pupuk kandang kambing dengan perbandingan 2:1 (v/v). Tanaman dipelihara sampai berumur 1 minggu dan diinokulasi dengan suspensi konidium Fusarium $\left(10^{6} \mathrm{~g}^{-1}\right.$ tanah) dengan cara menyiramkannya ke dalam medium tanam.

Pengamatan dilakukan selama 2 minggu dalam 5 kali pengamatan, yaitu saat tanaman berumur 7, 10, 14, 17, dan 21 hari setelah tanam (HST). Tanaman diukur tingginya serta diamati kemungkinan munculnya gejala penyakit. Tanaman dibiarkan tumbuh sampai berumur 7 minggu, kemudian dipotong pada pangkal batang untuk dihitung bobot kering tajuknya.

\section{Uji Lanjut Isolat}

Isolat cendawan yang memberikan pengaruh pertumbuhan tanaman yang lebih baik dibandingkan dengan kontrol (tanpa inokulasi) diuji kembali untuk mengetahui keefektifannya dalam menekan patogen layu kacang panjang ( $F$. oxysporum f. sp. tracheiphillum). Isolat $F$. oxysporum f. sp. tracheiphillum (Fot) koleksi Laboratorium Mikologi Tumbuhan, Departemen Proteksi Tanaman, IPB digunakan dalam uji ini.

Isolat Fot diremajakan pada medium PDA selama 7 hari. Potongan medium PDA yang mengandung cendawan dengan diameter $5 \mathrm{~mm}$ dimasukkan ke dalam medium beras steril dan diinkubasikan selama 2-3 minggu hingga cendawan tumbuh rata pada medium.

Tanah yang telah dicampur dengan pupuk kandang kambing dengan perbandingan 2:1 (v/v) dimasukkan ke dalam kantong berukuran $20 \mathrm{~cm}$ x $20 \mathrm{~cm}$. Sebanyak $5 \mathrm{~g}$ medium beras yang mengandung isolat Fot diaduk rata ke dalam tanah dan diinkubasi selama 5 hari. Benih kacang panjang yang direndam dalam suspensi isolat Fusarium uji selama 6 jam, selanjutnya ditanam pada medium yang sudah diinfestasi oleh isolat Fot. Pengamatan terhadap tinggi tanaman dan munculnya gejala layu dilakukan pada umur tanaman 7, 10, 14, 17, dan 21 HST.

\section{HASIL}

\section{Isolasi, Koleksi, dan Identifikasi Fusarium spp.}

Fusarium spp. yang diperoleh dari rizosfer tanaman kacang panjang dari Desa Cihideung Girang, Desa Sukawening, dan Desa Situgede, masing-masing sebanyak 21, 23, dan 12 isolat sehingga total diperoleh 56 isolat Fusarium. Isolat yang diperoleh pada masing-masing lahan memiliki keragaman spesies dan jumlah populasi per gram bobot kering tanah yang bervariasi. Spesies Fusarium yang diperoleh ialah 
F. solani, F. oxysporum, F. semitectum, $F$. longipes, dan Fusarium sp. Keragaman spesies Fusarium yang tertinggi diperoleh dari lahan contoh di Desa Sukawening, dengan sejarah pertanaman sebelumnya jagung (Tabel 1).

\section{Uji Peranan Isolat Fusarium pada Kacang Panjang.}

Isolat yang diujikan memberikan pengaruh yang bervariasi terhadap tinggi tanaman dan bobot kering tanaman (Gambar 1). F. solani dan $F$. oxysporum memberikan pengaruh pertumbuhan tinggi tanaman yang lebih baik daripada kontrol, sedangkan isolat $F$. semitectum, F. longipes, dan Fusarium sp. tidak berpengaruh pada pertumbuhan tinggi tanaman. Isolat $F$. solani, $F$. oxysporum, $F$. semitectum, $F$. longipes, dan Fusarium sp. yang memberikan pengaruh pertumbuhan tinggi tanaman yang sama dengan kontrol masing-masing sebanyak 3.6, 32.1, 19.6, 10.7, dan $8.9 \%$. Isolat $F$. oxysporum, $F$. semitectum, dan Fusarium sp. memberikan pengaruh pertumbuhan tinggi tanaman yang lebih kecil dari kontrol masing-masing sebanyak 7.1, 8.9, dan $5.4 \%$, sedangkan isolat $F$. solani dan $F$. longipes tidak ada yang memberikan pengaruh pertumbuhan tinggi tanaman yang lebih kecil daripada kontrol.

Isolat $F$. solani, $F$. oxysporum, dan Fusarium sp. yang memberikan pengaruh bobot kering tanaman yang lebih baik daripada kontrol masing-masing sebanyak $1.8,12.5$, dan $1.8 \%$, sedangkan isolat-isolat $F$. semitectum, dan $F$. longipes tidak ada yang memberikan pengaruh bobot kering tanaman yang lebih baik daripada kontrol. Isolat F. solani, F. oxysporum, F. semitectum, F. longipes, dan Fusarium sp. memberikan pengaruh bobot kering tanaman yang sama dengan kontrol masing-masing 1.8, 21.4, 10.7, 7.1, dan 3.6\%. Isolat F. solani, F. oxysporum, F. semitectum, F. longipes, dan Fusarium sp. yang memberikan pengaruh bobot kering tanaman lebih kecil dari kontrol masing-masing sebanyak 1.8, 7.1, 17.9, 3.6, dan $8.9 \%$.

Berdasarkan peubah tinggi dan bobotkering tanaman serta gejala kelayuan pada tanaman, dapat ditentukan 5 isolat yang memberikan pengaruh lebih baik dibandingkan dengan kontrol, yaitu SW2B2 (F. solani), ChGA1, ChGA2, ChGA5, dan ChGB1 (F. oxysporum).

Isolat yang memberikan pengaruh pertumbuhan sama dengan kontrol ada sebanyak 23 isolat, yaitu 1 isolat $F$. solani, 10 isolat $F$. oxysporum, 5 isolat $F$. semitectum, 4 isolat F. longipes, dan 3 isolat Fusarium sp. Isolat yang memberikan pengaruh pertumbuhan tanaman lebih kecil daripada kontrol sebanyak 25 isolat, yaitu 1 isolat $F$. solani, 6 isolat $F$. oxysporum, 11 isolat $F$. semitectum, 2 isolat F. longipes, dan 5 isolat Fusarium sp. Isolat cendawan yang menimbulkan gejala layu sebanyak 3 isolat, yaitu $\mathrm{ChGC1}$, ChUAb, dan SW2B1 yang semuanya diidentifikasi sebagai F. oxysporum. Tiga isolat ini menyebabkan pangkal batang tanaman berwarna cokelat kemerahan, mengeras dan kering, tulang daun berwarna kuning, dan tanaman tumbuh kerdil.

Tabel 1 Keragaman dan jumlah populasi cendawan Fusarium pada rizosfer kacang panjang dari berbagai lahan

\begin{tabular}{|c|c|c|c|c|c|c|c|c|}
\hline \multirow[b]{2}{*}{$\begin{array}{l}\text { Lokasi } \\
\text { lahan }\end{array}$} & \multicolumn{2}{|c|}{ Kondisi lahan } & \multicolumn{5}{|c|}{ Jumlah Fusarium (CFU/gram tanah) } & \multirow{2}{*}{$\begin{array}{c}\text { Indeks } \\
\text { keragaman } \\
\text { Shannon- } \\
\text { Weaner (H) }\end{array}$} \\
\hline & $\begin{array}{l}\text { Tanaman } \\
\text { sebelumnya }\end{array}$ & $\begin{array}{c}\text { Kejadian } \\
\text { penyakit layu } \\
\text { Fusarium (\%) }\end{array}$ & F sol & Fox & F sem & F long & $\begin{array}{l}\text { Fusarium } \\
\text { sp. }\end{array}$ & \\
\hline $\begin{array}{l}\text { Cihideung } \\
\text { Girang }\end{array}$ & Mentimun & 4.30 & 0 & 1400 & 200 & 300 & 200 & 0.433 \\
\hline Sukawening & Jagung & 2.89 & 300 & 900 & 600 & 200 & 300 & 0.635 \\
\hline Situgede & Gambas & 0 & 0 & 0 & 800 & 100 & 300 & 0.358 \\
\hline Total & & & 300 & 2300 & 1600 & 600 & 800 & \\
\hline
\end{tabular}

Keterangan: F sol, Fusarium solani; F ox, Fusarium oxysporum; F sem, Fusarium semitecteum; F long, Fusarium longipes 


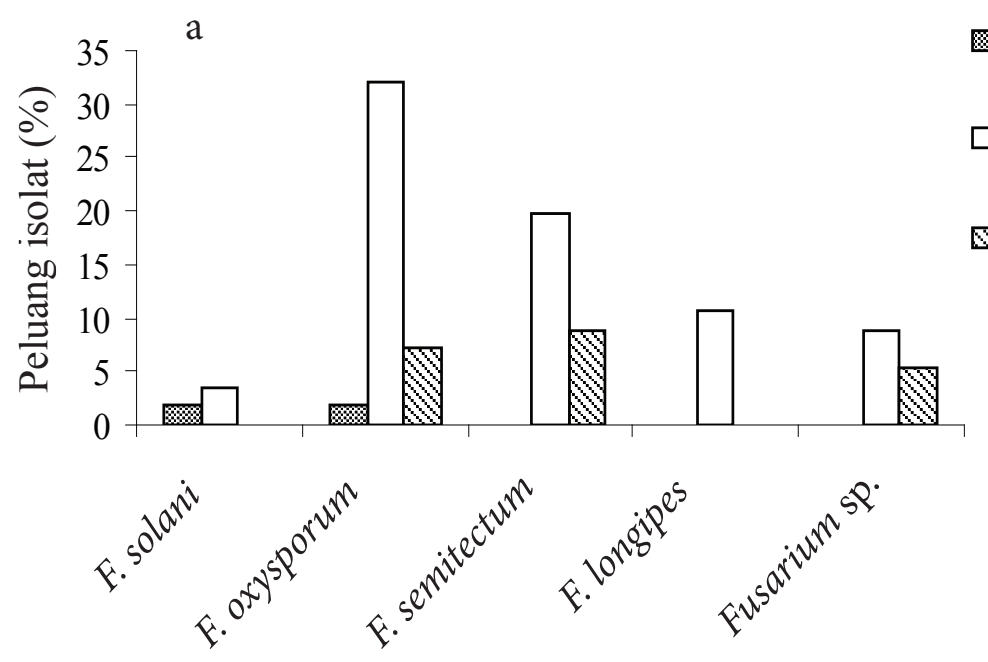

圆 Tinggi tanaman $>$ kontrol

$\square$ Tinggi tanaman sama dengan kontrol

Q 'Tinggi tanaman $<$ kontrol

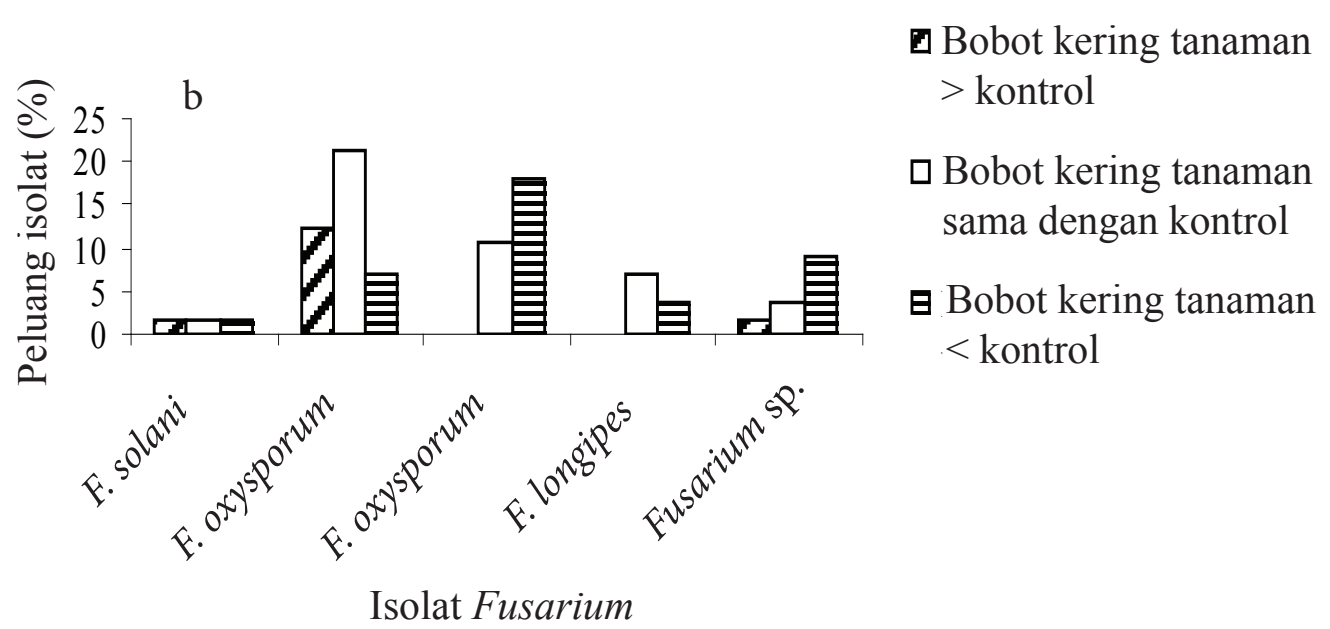

Gambar 1 Peluang pengaruh isolat Fusarium spp. terhadap pertumbuhan tanaman: a, tinggi tanaman; b, bobot kering tanaman.

Isolat yang memberikan pengaruh pertumbuhan (tinggi dan bobot kering) lebih baik daripada kontrol berasal dari lahan di Cihideung Girang sebanyak 4 isolat dan Sukawening sebanyak 1 isolat. Isolat yang berasal dari Sukawening dan Situgede banyak yang memberikan pengaruh pertumbuhan yang lebih kecil daripada kontrol (Gambar 2).

\section{Uji Lanjut Isolat}

Dari hasil pengamatan diperoleh 5 isolat yang diduga berpotensi untuk menekan $F$. oxysporum f. sp. tracheiphillum, yaitu isolat ChGA1, ChGA2, ChGA5, ChGB1 yang diidentifikasikan sebagai $F$. oxysporum dan SW2B2 yang diidentifikasi sebagai $F$. solani.

Hasil uji lanjut 5 isolat cendawan ini menunjukkan bahwa isolat tersebut mampu menekan perkembangan penyakit (Tabel 2).
Hal tersebut ditunjukkan dengan tidak ditemukannya gejala layu pada tanaman yang diinokulasi dengan 5 isolat tersebut sampai tanaman berumur 21 hari. Dari 5 tanaman yang hanya diinokulasi dengan $F$. oxysporum f. sp. tracheiphillum terdapat 3 tanaman yang menunjukkan gejala layu dan 2 tanaman lainnya tumbuh kerdil.

Selain mampu menekan perkembangan penyakit, beberapa isolat juga dapat menyebabkan pertumbuhan tanaman yang lebih baik. Sebanyak 2 isolat, ChGA2 dan ChGA5, mampu menekan perkembangan penyakit dan dapat memacu pertumbuhan tanaman (Gambar 3). Pada pengamatan hari ke-21 setelah inokulasi tinggi tanaman yang diinokulasi dengan kedua isolat tersebut masing-masing mencapai $78 \mathrm{~cm}$ dan $79 \mathrm{~cm}$ (Gambar 4). Isolat tersebut diidentifikasi 


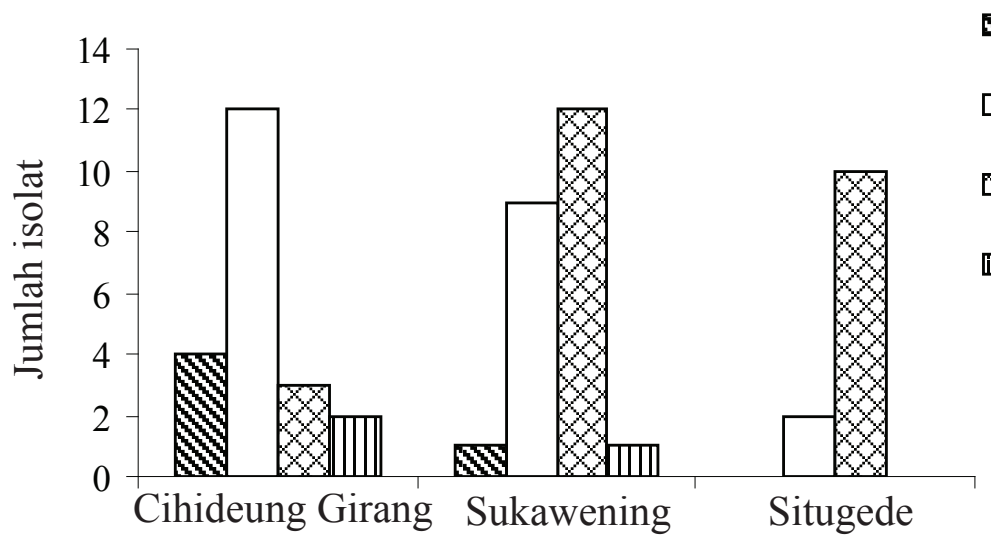

هertumbuhan tanaman > kontrol

口Pertumbuhan tanaman $=$ kontrol

Q Pertumbuhan tanaman $<$ kontrol

四 Kelayuan tanaman

Lahan

Gambar 2 Jumlah isolat dari masing-masing lahan sampel dan pengaruhnya pada pertumbuhan tanaman kacang panjang.

Tabel 2 Pengaruh isolat Fusarium terseleksi terhadap kejadian penyakit oleh Fusarium oxysporum f.sp tracheiphillum

\begin{tabular}{lcc}
\hline Perlakuan isolat & \multicolumn{2}{c}{ Gejala penyakit/jumlah tanaman contoh } \\
\cline { 2 - 3 } & kelayuan & kerdil \\
\hline Kontrol positif (Fot) & $3 / 5$ & $2 / 5$ \\
ChGA1 + Fot & $0 / 5$ & $0 / 5$ \\
ChGA2 + Fot & $0 / 5$ & $0 / 5$ \\
ChGA5 + Fot & $0 / 5$ & $0 / 5$ \\
ChGB1 + Fot & $0 / 5$ & $0 / 5$ \\
SW2B2 + Fot & $0 / 5$ & $0 / 5$ \\
Kontrol negatif (air) & $0 / 5$ & $0 / 5$ \\
\hline
\end{tabular}

Keterangan: Fot: F. oxysporum f.sp. tracheiphillum

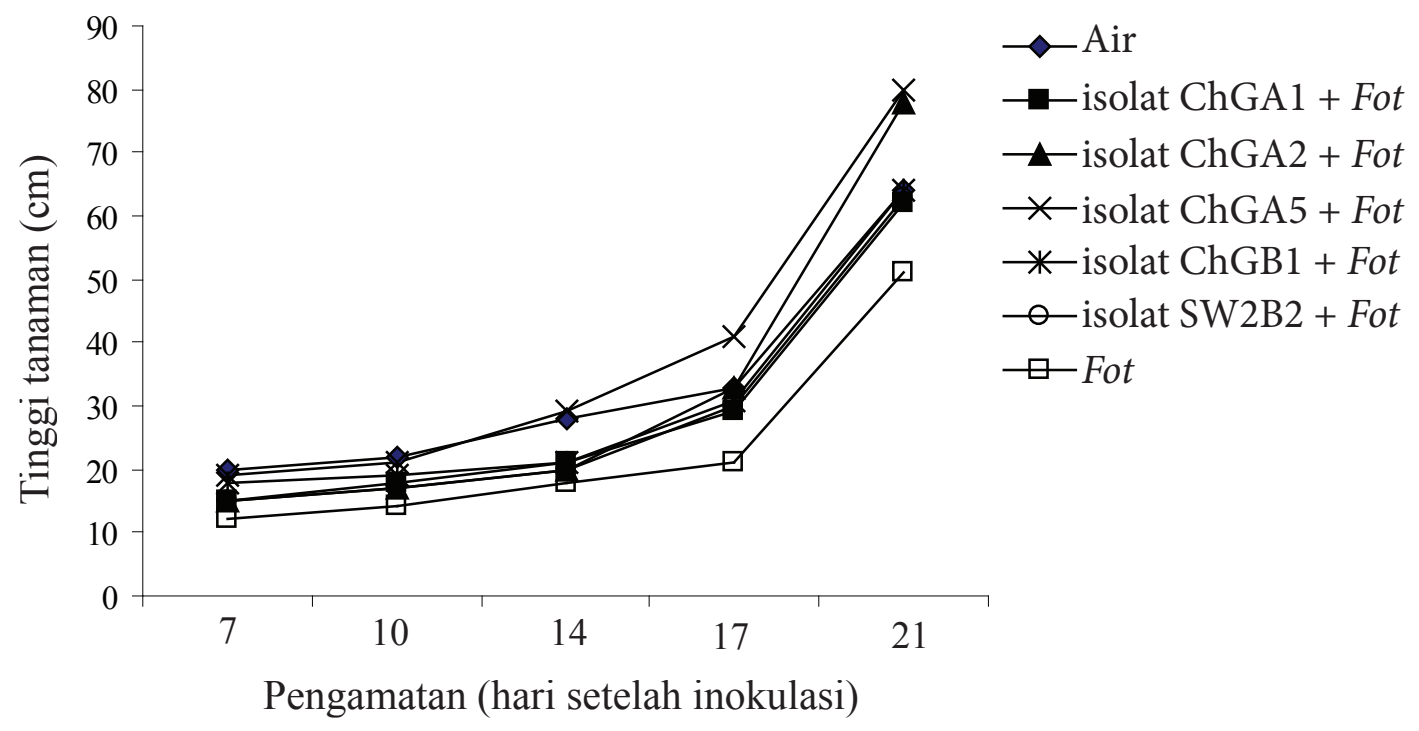

Gambar 3 Pengaruh 5 isolat Fusarium terseleksi dan Fusarium oxysporum f.sp. tracheiphillum (Fot) terhadap pertumbuhan tanaman. 


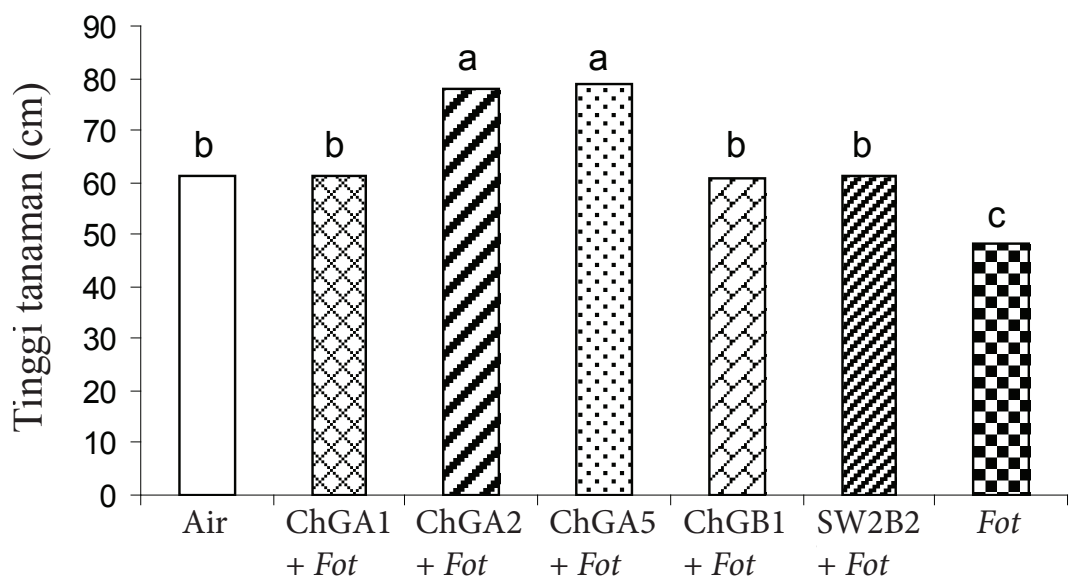

Gambar 4 Pengaruh koinokulasi isolat Fusarium terseleksi (ChGA1, ChGA2, ChGA5, ChGB1, SW2B2) dan F. oxysporum f.sp. tracheiphillum (Fot) terhadap tinggi tanaman yang diamati pada hari ke-21 setelah inokulasi.

sebagai $F$. oxysporum. Tanaman yang diinokulasi dengan isolat-isolat ChGA1, ChGB1, dan SW2B2 memberikan pertumbuhan tinggi tanaman yang tidak berbeda nyata dengan kontrol (Gambar 4). Tanaman yang diinokulasi hanya dengan $F$. oxysporum $\mathrm{f}$. sp. tracheiphillum tumbuh terhambat (Gambar 3) dan beberapa tanaman menunjukkan gejala layu.

\section{PEMBAHASAN}

Dari sejumlah spesies Fusarium yang diisolasi, $F$. oxysporum merupakan spesies dengan populasi yang paling banyak ditemukan. Dari beberapa penelitian lainnya tentang Fusarium yang mengolonisasi perakaran diketahui spesies ini yang mendominasi (El-Salaam et al. 2006). F. oxysporum dapat bersifat non patogen dan memiliki kemampuan menekan Fusarium yang patogen. Selain beberapa isolat $F$. oxysporum yang tidak menunjukkan gejala kelainan pertumbuhan tanaman ketika diinokulasi pada kacang panjang, ditemukan beberapa isolat yang menyebabkan kelayuan meskipun jumlahnya lebih sedikit. Isolat $F$. oxysporum yang menyebabkan kelayuan ini dikelompokkan ke dalam $F$. oxysporum f. sp. tracheiphilum penyebab penyakit pada tanaman kacang panjang (Armstrong dan Armstrong 1980). Rodrigues dan Menezes (2005) berhasil mengisolasi 8 spesies Fusarium endofit dari benih kacang, yaitu F. anthophilum, F. equiseti, $F$. oxysporum, F. moniliforme, F. semitectum, F. solani, F. sporotrichoides, dan Fusarium sp., tetapi semuanya tidak menyebabkan penyakit ketika diinokulasi pada tanaman kacang Vigna unguiculata kultivar rentan. Isolat standar F. oxysporum f. sp. tracheiphillum, sebagai pembanding, menunjukkan kelayuan. Dua spesies Fusarium, F. solani dan F. oxysporum, juga dilaporkan mendominasi pada beberapa contoh tanaman sakit di Iran, di antaranya mentimun, bit gula, sorgum, tomat, dan kacangkacangan (Chehri 2011). Dari penelitian kami, beberapa isolat yang sama seperti yang ditemukan oleh Rodrigues dan Menezes (2005), yaitu F. semitectum, F. solani, dan F. oxysporum juga tidak menunjukkan gejala kelayuan meskipun menghambat pertumbuhan tanaman kacang panjang (Gambar 1).

Isolat ChGA1, ChGA2, ChGA5, ChGB1, dan SW2B2t mampu menekan perkembangan patogen F. oxysporum f. sp. tracheiphillum dan juga dapat memacu pertumbuhan tanaman. Meera et al. (1994) melaporkan bahwa cendawan pemacu pertumbuhan tanaman juga mampu menekan perkembangan penyakit dan menginduksi ketahanan tananam secara sistemik. Isolat cendawan yang diisolasi dari rizosfer rumput-rumputan dapat menekan pertumbuhan koloni cendawan $F$. oxysporum f. sp. lycopersici secara in vitro dan dapat 
menekan perkembangan gejala layu Fusarium pada tanaman cabai merah di rumah kaca, selain juga dapat memacu pertumbuhan tanaman, terutama tinggi dan bobot basah tanaman (Purnama et al. 2000).

Dalam penelitian ini, selain ditemukan isolat yang dapat memacu pertumbuhan tanaman dan menekan perkembangan penyakit, juga terdapat 25 isolat yang menghambat pertumbuhan tanaman tanpa menimbulkan gejala layu atau penyakit pada tanaman. Isolat semacam ini sering disebut sebagai deleterious rhizosphere microorganisms (DRMO). Schippers et al. (1987) mendefinisikan DRMO sebagai patogen minor yang mempengaruhi tanaman dengan senyawa metabolitnya tanpa memarasit jaringan tanaman. Penghambatan pertumbuhan tanaman oleh mikroorganisme tersebut disebabkan oleh metabolit ekstrasel atau toksin yang dikeluarkannya. Adanya patogenisitas sulit ditunjukkan karena pengaruhnya pada tanaman ialah dengan menghambat pertumbuhan akar dan atau pucuk dengan sedikit gejala yang lain. Suslow dan Schroth (1982) juga menyatakan DRMO di antaranya telah diketahui dari kelompok bakteri dan cendawan. Populasi DRMO ini ternyata dapat ditekan oleh beberapa mikroorganisme bermanfaat yang dapat memacu pertumbuhan tanaman. Di lapangan hal ini dapat terjadi jika frekuensi penanaman tanaman yang sejenis tidak terlalu sering atau jika pola rotasi tanaman diterapkan.

Dari penelitian ini juga ditemukan beberapa isolat Fusarium yang jika diinokulasi di perakaran tanaman kacang panjang menunjukkan gejala layu, daun bagian bawah menguning, pangkal batang mengeras, dan tanaman tumbuh kerdil. Isolat tersebut termasuk dalam spesies $F$. oxysporum dan diduga sebagai $F$. oxysporum f. sp. tracheiphillum yang merupakan patogen penyebab layu pada tanaman kacang panjang (Booth 1971). Isolat tersebut diperoleh dari lahan Cihideung Girang dan Sukawening yang terserang layu. Isolat dari lahan Situgede dengan kejadian penyakit $0 \%$ pada waktu pengambilan contoh tanah, tidak ditemukan adanya Fusarium yang menyebabkan gejala layu pada tanaman, tetapi masih ditemukan isolat yang menekan pertumbuhan tanaman. Hal ini diduga karena populasinya sangat rendah karena didominasi oleh spesies Fusarium lain dan/atau komponen mikroorganisme lainnya.

Selain berperanan sebagai cendawan pemacu pertumbuhan tanaman, DRMO, atau patogen pada tanaman, isolat Fusarium yang ditemukan juga ada yang hanya bersifat saprob di dalam tanah dan tidak berpengaruh secara nyata terhadap pertumbuhan tanaman. Meskipun isolat Fusarium dari Situ Gede tidak ditemukan yang bersifat patogen dan ini juga ditunjukkan tidak adanya gejala layu pada saat pengambilan contoh, namun juga tidak ditemukan yang bersifat memacu pertumbuhan dan lebih didominasi oleh isolat yang bersifat menekan pertumbuhan tanaman. Komposisi isolat dari Cihideung Girang dan Sukawening lebih beragam akan spesies dan peranannya. Keragaman ini ternyata juga tidak berhubungan dengan tingkat kejadian penyakit di lapangan karena salah satu komponen penyusun keragaman ini ialah spesies patogen pada tanaman kacang panjang. Pemahaman tentang keragaman peranan maupun spesies Fusarium yang dihubungkan dengan tingkat kejadian penyakit, sejarah pertanaman, dan produktivitas tanaman masih perlu diteliti lebih lanjut. Fusarium pemacu pertumbuhan tanaman yang diperoleh, $F$. oxysporum dan $F$. solani, memiliki peluang besar untuk digunakan sebagai agens pengendali hayati layu Fusarium pada kacang panjang. Spesies yang sering disebut sebagai Fusarium non patogen telah banyak diteliti sebagai pengendali hayati penyakit layu Fusarium (Widodo 2000; Nel et al. 2006a). Dalam beberapa kasus tanah supresif terhadap penyakit layu Fusarium atau dari tanaman yang sehat, Fusarium non patogen berperanan penting sebagai penekan populasi Fusarium patogen dan/atau menginduksi ketahanan tanaman sehingga penyakit tidak muncul (Nel et al. 2006b; Dumroese et al. 2012). 


\section{DAFTAR PUSTAKA}

Abdel Hafeez SII, Ismail MA, Hussein NA, Abdel-Hameed NA. 2012. Fusaria and oher taxa associated with rhizhosphere and rhizoplane of lentil and sesame at different growth stages. Acta Mycol. 47(1):35-48.

Appel DJ, Gordon TR. 1994. Local and regional variation in populations of Fusarium oxysporum from agricultural field soils. Phytopathology. 84(8):786-791. doi: 10.1094/Phyto-84-786.

Armstrong GM, Armstrong JK. 1980. Cowpea wilt Fusarium oxysporum f.sp. tracheiphilum race 1 from Nigeria. Plant Dis. 64(10):954-955. doi:10.1094/PD-64954.

Booth C. 1971. The Genus Fusarium. Kew, Surrey (GB): CMI.

Chehri K. 2011. Occurrence of Fusarium species associated with economically important agricultural crops in Iran. Afr J Microbiol Res. 5(24):4043-4048. doi: 10.5897/AJMR10.158.

Dumroese RK, Kim MS, James RL. 2012. Fusarium oxysporum protects Douglas Fir (Pseudotsuga menziesii) seedlings from root disease caused by Fusarium commune. The Plant Pathol J. 28(3):311316. doi 10.5423/PPJ.NT.08.2011.0155.

Edel V, Steinberg C, Gautheron N, Alabouvette C. 1997. Populations of non pathogenic Fusarium oxysporum associated with roots of four plant species compared to soil-borne populations. Phytopathology. 87(7):693697. doi: 10.1094/PHYTO.1997.87.7.693.

El-Salam KAA, Amal AMA, Omar MR, Aly AA. 2006. Frequency and diversity of Fusarium spp. colonizing roots of Egyptian cottons. Arch Phytopathol Plant Protect. 39(3):165-177. doi: 10.1080/032 35400400007533.

Forsyth LM, Smith LJ, Aitken EAB. 2006. Identification and characterization of non pathogenic and pathogenic Fusarium oxysporum capable of increasing and decreasing Fusarium wilt severity. Mycol Res. 110:929-925. doi:10.1016/j. mycres.2006.03.008.
Kaur R, Kaur J, Singh RS. 2010. Nonpathogenic Fusarium as biological control agent. Plant Pathol J. 9(3):79-91.

Krebs CJ. 1972. Ecology: The experimental analysis of distribution and abundance. New York (US): Harper and Row Publishers, Inc.

Latifah Z, Padzilah MI, Salleh B, Maziah Z. 2009. Fusarium species in forest of Bird Valey. Malay J Microbiol. 5(2):132-133.

Leslie JF, Summerell BA. 2006. The Fusarium Laboratory Manual. Ed ke-1. Iowa(US): Blackwell Publishing.

Meera MS, Shivanna MB, Kageyama K, Hyakumachi M. 1994. Plant growth promoting fungi from zoysiagrass rhizosphere as potentian inducers of systemic resistance in cucumbers. Phytopathology. 84(12):1399-1406. doi: 10.1094/Phyto-841399.

Nash SM, Snyder WC. 1962. Quantitative estimation by plat counts of propagules of the bean root rot Fusarium in field soils. Phytopathology. 52(6):567-572.

Nel B, Steinberg C, Labuschagne N, Viljoen A. 2006b. Isolation and characterization of nonpathogenic Fusarium oxysporum isolates from the rhizosphere of healthy banana plants. Plant Pathol. 55:207-216. doi: 10.1111/j.1365-3059.2005.01343.x.

Nel B, Steinberg C, Labuschagne N, Viljoen A. 2006a. The potential of non pathogenic Fusarium oxysporum and other biological control organisms for suppressing Fusarium wilt of banana. Plant Pathol. 55:217-223. doi: 10.1111/j.1365-3059.20 06.01344.x.

Ocamb CM, Kommedahl T. 1994. Rhizosphere competence of Fusarium species colonizing corn roots. Phytopathology. 84(2): 166-172. doi:10.1094/Phyto-84-166.

Purnama A, Yulia E, Nasahi C. 2000. Isolasi jamur rizosfer rumput-rumputan dan pengujian efeknya terhadap penyakit layu Fusarium pada tanaman cabai merah [skripsi]. Bandung (ID): Universitas Padjadjaran.

Rodrigues AAC, Menezes M. 2005. Identification and pathogenic characteri- 
zation of endophytic Fusarium species from cowpea seeds. Mycopathologia. 159(1):79-85. doi: 10.1007/s11046-0047138-x.

Schippers B, Bakker AW, Bakker PAHM. 1987. Interactions of deleterious and beneficial rhizosphere microorganisms and the effect of cropping practices. Ann Rev Phytopathol. 25:339-358. doi 10.1146/annurev.py.25.090187.002011.

Scisel JJ, Kurek E, Winiarczyk, Baturo A, Lukanowski A. 2008. Colonization of root tissues and protection against Fusarium wilt. Biol Contrl. 45:297-307. doi: 10.1016/ j.biocontrol.2008.03.007.

Suslow TV, Schroth MN. 1982. Role of deleterious rhizobacteria as minor pathogens in reducing crop growth. Phytopathology. 72(1):111-115. doi: 10.1094/Phyto-72-111.
Summerell BA, Laurence MH, Liew ECY, Leslie JF. 2011. Biogeography and phylogeography of Fusarium: a review. Fungal Divers. 44:3-13. doi 10.1007/s1 3225-010-0060-2

Summerell BA, Salleh B, Leslie JF. 2003. A utilitarian approach to Fusarium identification. Plant Dis. 87(2):117-128. doi: 10.1094/PDIS.2003.87.2.129.

Toussoun TA, Nelson PE. 1975. Fusarium, A Pictorial Guide to The Identification of Fusarium Species According to the Taxonomic System of Snyder and Hansen. Ed ke-2. Pennsylvania (US): The Pennsylvania State University Press.

Widodo. 2000. Studies on the biological control of Fusarium basal rot of onion caused by Fusarium oxysporum f. sp. cepae [disertasi]. Sapporo (JP): Hokkaido Univ. 